Research article

\title{
Change in physico-chemical character of nutrient media and carpet effluent in presence of six algae monocultures and their consortia
}

\author{
Akash Kumar Patel ${ }^{1}$, M. R. Suseela ${ }^{1},{\text { Munna } \operatorname{Singh}^{2} \text { and Sanjeeva Nayaka }}^{1}$ * \\ ${ }^{1}$ Algology Section, Plant Biodiversity and Conservation Biology Division, CSIR-National Botanical Research \\ Institute, Lucknow-226001, Uttar Pradesh, India \\ ${ }^{2}$ Department of Botany, University of Lucknow, Lucknow-226007, Uttar Pradesh, India
}

*Corresponding Author: nayaka.sanjeeva@gmail.com

[Accepted: 21 May 2017]

\begin{abstract}
Synthetic microalgae ecology is a promising approach to regulate the concentrations of nutrients in wastewater reservoirs. The aim of experiments was to evaluate the role of six microalgae monocultures and their consortia in restoring the water quality of water reservoirs

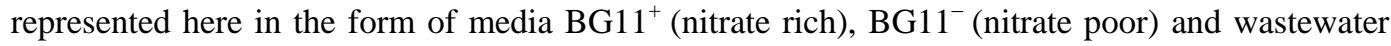
from carpet effluent (CE). The algal species utilized in the present experiment were Anabaena sp., Chlorella sp., Oscillatoria sp., Nannochloropsis sp., Scenedesmus sp., Phormidium sp., and their synthetic consortia. The water parameters analyzed were dissolved oxygen (DO), water conductivity, $\mathrm{pH}$ and concentrations of nutrients (nitrates, phosphates, nitrites). We observed that Chlorella sp. produced maximum biomass of $2.217 \pm 0.126$ g. $\mathrm{L}^{-1}$ in $\mathrm{BG} 11^{+}$media followed by Anabaena sp. $1.897 \pm 0.045$ for BG11 ${ }^{-}$media and $1.233 \pm 0.29 \mathrm{~g} . \mathrm{L}^{-1}$ for synthetic consortia of BG11 media. On other hand, biomass yields of $1.233 \pm 0.017$ and $0.460 \pm 0.010$ g. $\mathrm{L}^{-1}$ were obtained respectively for consortia in the nitrate deficient $\mathrm{BG} 11^{-}$media and $\mathrm{CE}$ water. Consequently, with

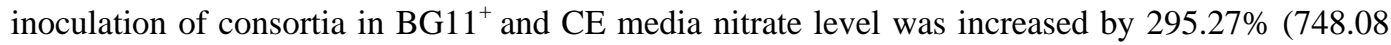

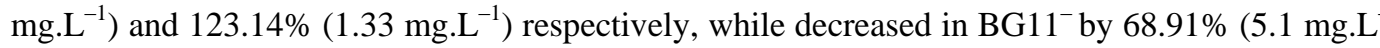
$\left.{ }^{1}\right)$. Nitrite concentration was enhanced up to $35.52,0.038$ and $0.028 \mathrm{mg} \cdot \mathrm{L}^{-1}$ in BG11 ${ }^{+}$, BG11 ${ }^{-}$and CE respectively. In contrast, with inoculation of the consortia, the phosphate levels were found to be depleted by $35.35 \%$ (1.31 mg. $\left.\mathrm{L}^{-1}\right)$ in BG11 $1^{+}$, 95.72\% (3.64 mg. $\left.\mathrm{L}^{-1}\right)$ in $\mathrm{BG}^{-} 1^{-}$and $94.97 \%$ (1.7 $\left.\mathrm{mg} . \mathrm{L}^{-1}\right)$ in $\mathrm{CE}$ respectively. The range of $\mathrm{pH}$ value and $\mathrm{DO}$ for different media was found between 8.25-8.87 and 6.14-10.54 mg. $\mathrm{L}^{-1}$ respectively, and conductivity was increased with the growth of algae. The study suggests that beneficial algae and their consortia can be logically selected for biomass production and for improving the water quality.
\end{abstract}

Keywords: Wastewater treatments - Microalgae consortia - Water parameters - Biomass - Carpet effluent.

[Cite as: Patel AK, Suseela MR, Singh M \& Nayaka S (2017) Change in physico-chemical character of nutrient media and carpet effluent in presence of six algae monocultures and their consortia. Tropical Plant Research 4(2): 192-202]

\section{INTRODUCTION}

The idea of employing the microalgae for wastewater treatments has been originated about six decades ago (Oswald et al. 1957). Today microalgae are widely utilized in industrial and household wastewater treatments. These microalgae can perform photosynthesis to generate their own energy and releases excess amount of $\mathrm{O}_{2}$ to the atmosphere. Microalgae wastewater treatment plants require minimal supply of energy resources that reduces the use of sophisticated instruments such as energy-intensive electromechanical blowers (Green et al. 1995), catalytic hydrothermal gasification (Elliott 2008), anaerobic digestion (McCarty et al. 2011) and hydrothermal liquefaction (Chakraborty et al. 2012). In conventional wastewater treatments nitrate is converted into the $\mathrm{N}_{2}$ gas through the oscillation within nitrification or denitrification system while phosphates are 
precipitated by metal salts. Microalgae remove nitrates and phosphates in more eco-friendly manner. Through mixotrophic metabolism, microalgae consortia could perform better and can be used as a sustainable method for treatment of wastewater. Mixotrophic metabolism utilizes nitrate and phosphate from wastewater to enhance microalgae biomass (Henkanatte-Gedera et al. 2015). Microalgae consortia based wastewater treatments has numerous advantages over the conventional methods. The consortia could be efficient in detoxification of organic and inorganic pollutants from wastewater as compared to the individual microalgae (Subashchandrabose et al. 2011). Natural consortia improve water quality (bioremediation of hazardous waste viz. nitrates and phosphates), soil quality (nutrient recycling), plant health etc., and help in maintaining the major ecosystem (Lugtenberg \& Kamilova 2009, Gilbert et al. 2012, Craggs et al. 2013, Samorı`et al. 2013). Engaging microalgae consortia for the nutrient recycling in different wastewater reservoirs to produce biomass for a broad range of value added bio-chemicals (Martins et al. 2010) has revitalized the concept of synthetic microalgae ecology as emerging technology (Pittman et al. 2011, Craggs et al. 2013).

Microalgae require nitrate and phosphate in a specific ratio for biomass production. Therefore, removal of nitrate depends on the levels of phosphate in wastewater and vice-versa. In household wastewater nitrate occurs between 15 to $90 \mathrm{mg} . \mathrm{L}^{-1}$ while levels of phosphate vary between 4 to $20 \mathrm{mg} . \mathrm{L}^{-1}$ (Christenson \& Sims 2011, Abdelaziz et al. 2013, Cai et al. 2013). Microalgae utilize N and P in various biochemical reactions to produce a number of primary and secondary metabolites that alternatively determine the overall biochemical composition of biomass (Klausmeier et al. 2004, Loladze \& Elser 2011). Nitrogen participates in the synthesis of protein while phosphorus helps in the synthesis of ribosomal RNA and ribosome (French et al. 2003, Dennis et al. 2009). A number of studies have shown that lower supply of nitrate and phosphate resulted in more accumulation of carbohydrate or lipid or both in their biomass. However, their higher levels increase the algae biomass as well as their concentration in water or media (Xin et al. 2010, Arbib et al. 2013, Samor` et al. 2013, Beuckels et al. 2015). Published literature showed that the concentration of any one nutrient (either nitrate or phosphate) fluctuate at a time while other remains constant (Xin et al. 2010, Arbib et al. 2013, Samori et al. 2013, Zhang \& Hong 2014). Therefore, levels of both nutrients vary simultaneously without changing their ratios (Aslan \& Kapdan 2006, Akerström et al. 2014). At high levels of nitrate reduced absorption of phosphate from water has been reported (Pittman et al. 2011, Craggs et al. 2013). High amount of nitrate content reduces the nitrate uptake. In the presence of high amount of nitrate, some algae synthesize nitrate (Philips et al. 1992). Nutrient availability influences the biochemical composition of microalgae biomass that alternatively provokes the biosynthesis of some primary and secondary metabolites. Keeping their facts in view the aim of present study is to know up to what extent the microalgae monocultures and their consortia can mitigate the levels of nitrate, nitrite and phosphate in carpet effluent (CE), and how they respond to $\mathrm{BG} 11^{+}$and $\mathrm{BG} 11^{-}$media supplemented with and without nitrate respectively. We have also evaluated that up to what extent the water physico-chemical parameter in media and natural CE water can affect the physiology and biomass production.

\section{MATERIALS AND METHODS}

Algae Cultures

Six different microalgae species belonging to three phyla such as Cyanophyta (Anabaena sp., Oscillatoria sp., Phormidium sp.), Orchrophyta (Nannochloropsis sp.) and Chlorophyta (Chlorella sp., Scenedesmus sp.) were isolated and purified from the carpet industries effluent of Bhadohi district, Uttar Pradesh, India. These microalgae monocultures were regularly maintained on $\mathrm{BG}_{1} 1^{+}$agar plates as well as in the liquid $\mathrm{BG} 1^{+}$media. Each algae taxon was identified by following the standard procedures and relevant literature (Desikachary 1959, Philipose 1967, Hibberd 1981). CE media was sterilized through $0.22 \mu \mathrm{m}$ membrane filter while $\mathrm{BG} 11^{+}$and BG11 ${ }^{-}$media were steam sterilized. All the cultures were incubated at $27 \pm 1^{\circ} \mathrm{C}$ temperature with an illumination of $92 \mu$ mole. $\mathrm{m}^{-2} . \mathrm{S}^{-1}$ photons in a regime of $14: 10$ light-dark period in $500 \mathrm{~mL}$ microcosms.

\section{Experimental design}

A set of 21 experiments were executed in $200 \mathrm{~mL}$ of sterilized $\mathrm{BG} 11^{+}, \mathrm{BG} 11^{-}$media and $\mathrm{CE}$ water for six monocultures and their synthetic consortia in three replications. The BG1 $1^{+}$media was supplemented with 1.5 g. $\mathrm{L}^{-1} \mathrm{NaNO}_{3}$ while BG11- media was maintained without nitrate supplement and $\mathrm{CE}$ acted as natural media. The algae biomasses were harvested after 35 days of cultivation, and dried biomass was obtained by the gravimetric method. At the end of experiments, different physico-chemical parameters such as changes in the $\mathrm{pH}$ values, dissolved oxygen, water conductivity, nitrates, nitrites and phosphate of the cell-free supernatants of 
different media were analyzed by using DREL 2800 Complete Water Quality Lab with Meter (Hach Co. USA).

Statistics

All the data for different physico-chemical parameters yields were analysed statistically by two-way ANOVA followed by post hoc Bonferroni analysis, significant differences among the treatments were considered at $95 \%$ confidence level $(P$ value $<0.05)$. Various graphs were prepared using the Graph Pad Prism $^{\mathrm{TM}}$ (version 5.0, GraphPad Software). All the experiments were done in three replications, and data presented here as mean and standard deviation in graphs and in tables.

\section{RESULTS AND DISCUSSION}

\section{Estimation of physico-chemical parameters}

The $\mathrm{pH}$ of cultivation media was variably influenced by the growth of monocultures and their synthetic consortia, and an interesting pattern was observed. The $\mathrm{pH}$ values were found to be in the range between 8.25 to 8.87 for different monocultures and consortia. The initial $\mathrm{pH}$ value was found to be highest in the case of both nitrate enriched $\mathrm{BG} 11^{+}(9.02 \pm 0.00)$ and nitrate deprived $\mathrm{BG} 11^{-}(8.69 \pm 0.01)$ media, while it was lowest in natural CE $(7.93 \pm 0.58)$ water. The $\mathrm{pH}$ invariably increased in $\mathrm{CE}$ with inoculation of monocultures and consortia, and highest change was found in the case of consortia. The $\mathrm{pH}$ value was considerably decreased in BG11 ${ }^{+}$with growth of Anabaena sp. while in $\mathrm{BG}^{+} 1^{+}$with Nannochloropsis sp. Significant changes in $\mathrm{pH}$ were recorded with growth of Anabaena sp. in $\mathrm{BG}_{1} 1^{+}(P<0.001), \mathrm{CE}(P<0.001)$ and $\mathrm{BG}^{-} 1^{-}(P>0.05$, ns $)$, and

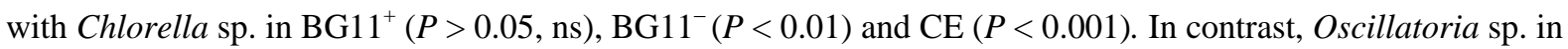
BG11 ${ }^{+}$did not affect the $\mathrm{pH}(P>0.05, \mathrm{~ns})$ while it significantly affected in BG11 $1^{-}(P<0.001)$ and $\mathrm{CE}(P<$ 0.001). On other hand, Nannochloropsis sp. affected the $\mathrm{pH}$ of CE $(P<0.001)$, Scenedesmus sp. significantly

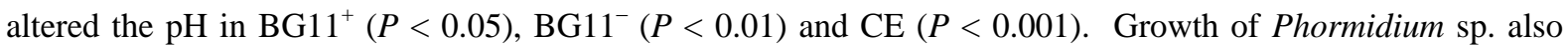
affected the $\mathrm{pH}$ significantly in $\mathrm{BG} 11^{+}, \mathrm{BG} 11^{-}(P<0.01)$ and $\mathrm{CE}(P<0.001)$. Consortia significantly altered the $\mathrm{pH}$ in $\mathrm{BG}_{1} 1^{+}(P<0.05), \mathrm{BG}_{1} 1^{-}(P<0.01)$ and $\mathrm{CE}(P<0.001)$ when compared with respective controls. The means of $\mathrm{pH}$ and their standard deviation are given in figure 1.

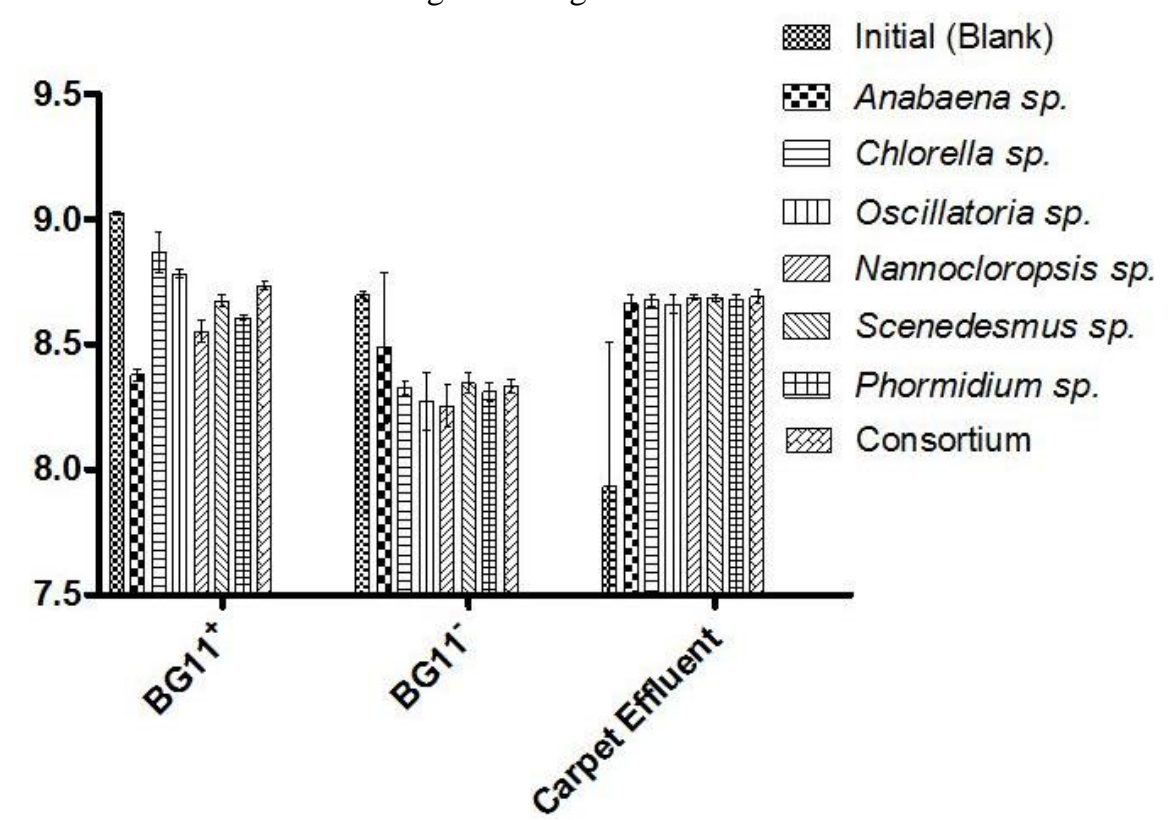

Figure 1. pH of media and carpet effluent of blank (Initial) after growth of monoculture and consortia.

The monocultures have some distinct inherent traits that determine their metabolic features and morphological appearance. However, variations in environmental conditions could highly influence their physiology and morphology (Smith \& Schindler 2009). A little variation in the environment can affect their metabolite profile and biomass (Piersma \& Drent 2003), and $\mathrm{pH}$ is one of the major factors that affect the physiology including growth rates, primary and secondary metabolite production. Most of the algae can make their own food through the process of photosynthesis which involves a number of enzymes that work optimally at a particular $\mathrm{pH}$. When we cultured these monocultures and consortia, $\mathrm{pH}$ of different growth media fluctuated in a wide range. Any variation in the $\mathrm{pH}$ can affect the function or may denature those important enzymes which are involved in the photosynthesis. Alternatively, it affects the overall biomass yields. Since $\mathrm{CO}_{2}$ is a major www.tropicalplantresearch.com 
byproduct of respiration, microalgae utilizes $\mathrm{CO}_{2}$ and water during photosynthesis to produce the photosyntax, carbonic acid that alternatively decreases the $\mathrm{pH}$ (Wurts \& Durborow 1992). Therefore, $\mathrm{pH}$ values of the media and $\mathrm{CE}$ water oscillated between 8.25 and 8.87 for optimal $\mathrm{CO}_{2}$ sequestration. As more $\mathrm{CO}_{2}$ is absorbed into the solution, the acidity of the solution gradually increases. At the higher acidity point no more $\mathrm{CO}_{2}$ can be absorbed. The change in $\mathrm{pH}$ is responsible for the increased synthesis of biomass by carbon fixation reactions. The $\mathrm{pH}$ of $\mathrm{CE}$ media was increased from 7.93 to 8.69 for all the organisms and consortia which indicate that it is the range of $\mathrm{pH}$ at which these organisms could grow well in natural water reservoirs (Yeh et al. 2005).

Initial dissolve oxygen recorded in $\mathrm{BG} 11^{+}$was $6.79 \pm 0.02 \mathrm{mg} \cdot \mathrm{L}^{-1}$, in $\mathrm{BG} 11^{-}$media $6.83 \pm 0.02$ and in $\mathrm{CE}$ water $2.64 \pm 0.02 \mathrm{mg} . \mathrm{L}^{-1}$. In all the experiments Anabaena sp. and Chlorella sp. significantly increased DO levels in media and effluent water at a range of $9.70 \pm 0.05$ to $10.54 \pm 0.16 \mathrm{mg} . \mathrm{L}^{-1}$. Monoculture namely Anabaena sp., Chlorella sp., Oscillatoria sp., Scenedesmus sp., Phormidium sp. and consortia significantly optimized $(P<$ $0.001)$ the DO levels of media and CE water. Nannochloropsis sp. could not improve the DO content of BG11 ${ }^{+}$ and $\mathrm{BG}_{1} 1^{-}(P>0.05, \mathrm{~ns})$ while improved significantly in $\mathrm{CE}$ water $(P<0.001)$. Mean values and standard deviation of DO of cell-free supernatant for different culture media are shown in figure 2. In general, if consumption of DO is more than the production its level declines.

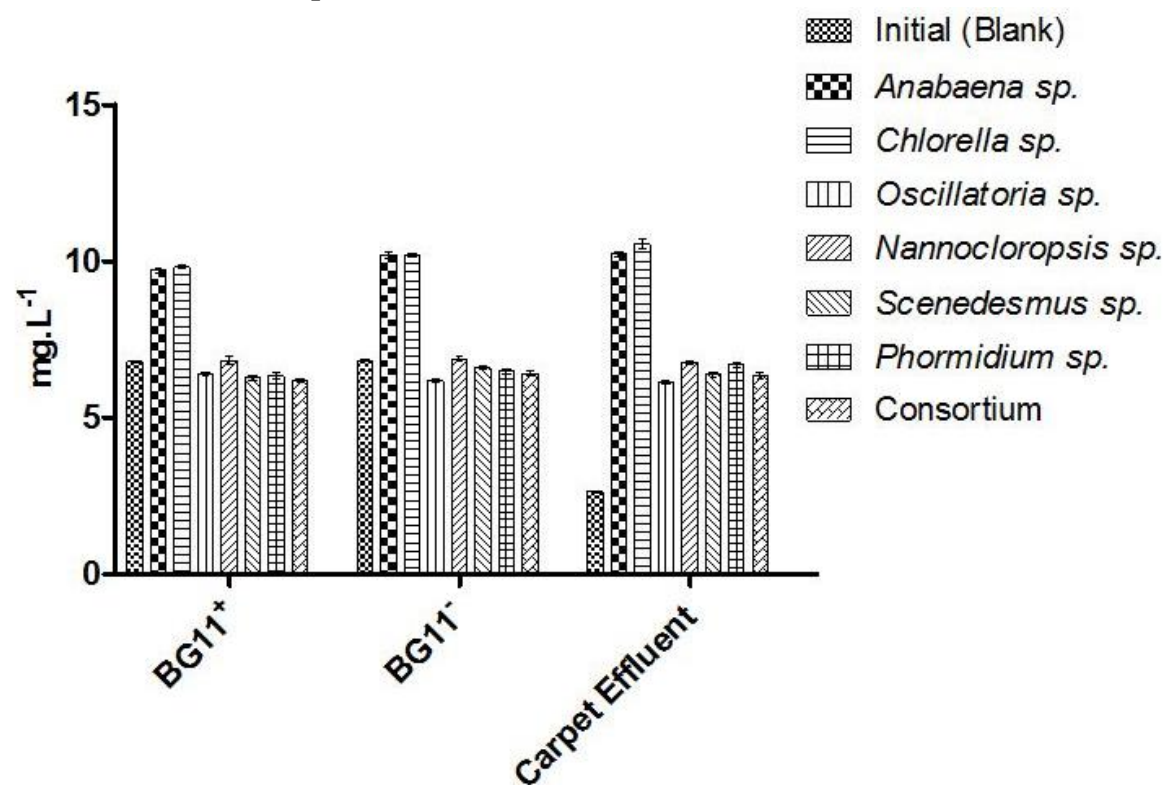

Figure 2. Dissolve oxygen of media and carpet effluent of blank (Initial) after growth of monoculture and consortia.

The microbial growth is directly related to the available amounts of nutrient and DO in water. Here, we found that the DO level of un-inoculated CE media was lowest when compared to BG11 ${ }^{-}$and $\mathrm{BG} 11^{+}$media. However, after inoculation, DO level significantly increase up to 5 folds. Microalgae growth significantly increased the DO levels by releasing the oxygen that added to the media of their growth. In the case of Anabaena sp. and Chlorella sp. highest DO levels were observed than other microalgae in all the three media with its maximum values in CE. Therefore, inoculation of Anabaena sp. and Chlorella sp. in CE water could significantly enhance DO levels. In contrast, the lowest increase in DO levels was observed in all the media with inoculation of algae consortia.

DO levels varies with temperature and altitude, cold water holds more oxygen than warm water but at the higher altitude water holds less oxygen. DO concentrations highly depend on the photosynthetic rates of microalgae and levels of nutrients in the water. In general, high temperature and salinity reduce oxygen levels. The maximum amount of DO (7.95 mg. $\mathrm{L}^{-1}$ ) occurs at $27^{\circ} \mathrm{C}$ (Manasrah et al. 2006). In our study at the end of experiment DO was found to be in the range between 6.14-10.54 mg. $\mathrm{L}^{-1}$. However, published literature of microalgae consortia showed the range of DO between 6.2-6.4 mg. $\mathrm{L}^{-1}$ (Badran 2001, Renuka et al. 2013).

Initial conductivity recorded in $\mathrm{BG} 11^{+}, \mathrm{BG} 11^{-}$media and $\mathrm{CE}$ water were 2440.0 $\pm 10.0,351.6 \pm 7.6$ and 934.0 \pm 8.5 respectively. Conductivity increased in all set of experiments expect for Anabaena sp. and Chlorella sp.in $\mathrm{CE}$ water. In BG11 ${ }^{+}$and $\mathrm{BG} 11^{-}$media, inoculation of all the monocultures and consortia significantly increased the water conductivity. Oscillatoria sp. significantly enhanced the water conductivity in all the media. Anabaena sp. significantly increased in $\mathrm{BG}_{1}{ }^{+}(P<0.001)$ and $\mathrm{CE}$ water $(P<0.01)$ whilst in $\mathrm{BG}^{-} 1^{-}(P>0.05$, 
ns) it did not affected significantly. On other hand, significant changes in conductivity were recorded with inoculation of Chlorella sp. (BG11 ${ }^{+}, P<0.01$ ), Oscillatoria sp. (BG11 ${ }^{+}$and CE, $P<0.001$ ), Nannochloropsis sp. (BG11 $\left.{ }^{+}, P<0.001\right)$, Scenedesmus sp. (BG11 $\left.{ }^{-}, P<0.05\right)$, Phormidium sp. (BG11 $\left.{ }^{+}, P<0.001\right)$ respectively. In contrary, the consortia could change the conductivity only in ${\mathrm{BG} 11^{+}}^{+}(P<0.001)$. The mean values of conductivity along with their standard deviation are presented in figure 3 .

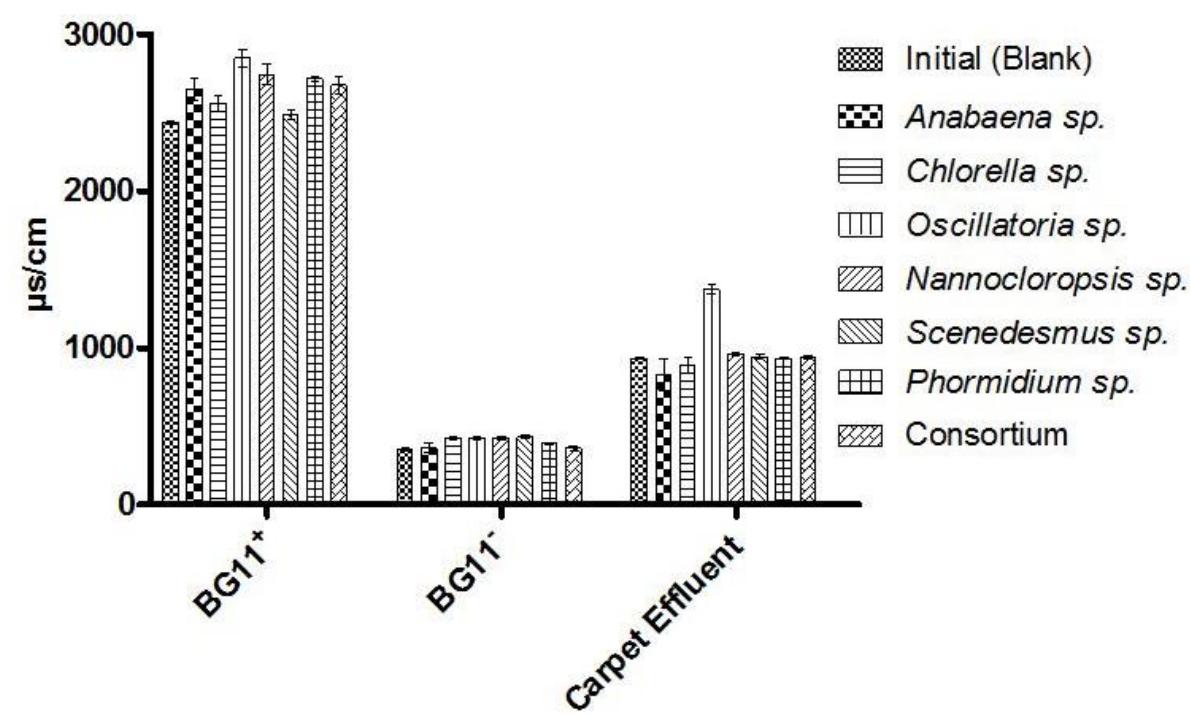

Figure 3. Conductivity of media and carpet effluent of blank (Initial) after growth of monoculture and consortia.

Since water conductivity is used to measure the ability of water to carry the electricity, pure water is considered as a poor conductor. It is the main reason that water shows significant conductivity in the presence of dissolved salts. In general, conductivity is directly proportional to the amount of dissolved salts in the water (Iyasele \& Idiata 2015), and microalgae growth increases the water conductivity (Potapova \& Charles 2003). Microalgae growth adds a number of minerals such as iron, nitrogen and phosphorus, which significantly involve in enhancing the water conductivity (Townsend et al. 2012). In addition, the increased water conductivity and the algae density have a direct relationship (Potapova \& Charles 2003, Anonymous 2012).

\section{Biomass Estimation}

Biomass production was found to be highest in the case of Chlorella sp. $\left(2.217 \pm 0.126\right.$ g. $\left.\mathrm{L}^{-1}\right)$ in BG11 ${ }^{+}$

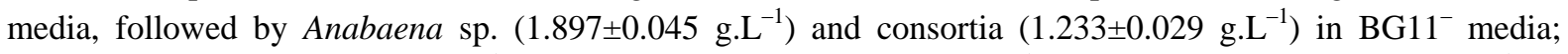
Phormidium sp. $\left(1.103 \pm 0.057\right.$ g.L $\left.\mathrm{L}^{-1}\right)$, Scenedesmus sp. $\left(1.020 \pm 0.026\right.$ g. $\left.\mathrm{L}^{-1}\right)$ and consortia $\left(0.923 \pm 0.025 \mathrm{~g} . \mathrm{L}^{-1}\right)$ in BG11 $1^{+}$media. Biomasses produced by different cultures are shown in figure 4 .

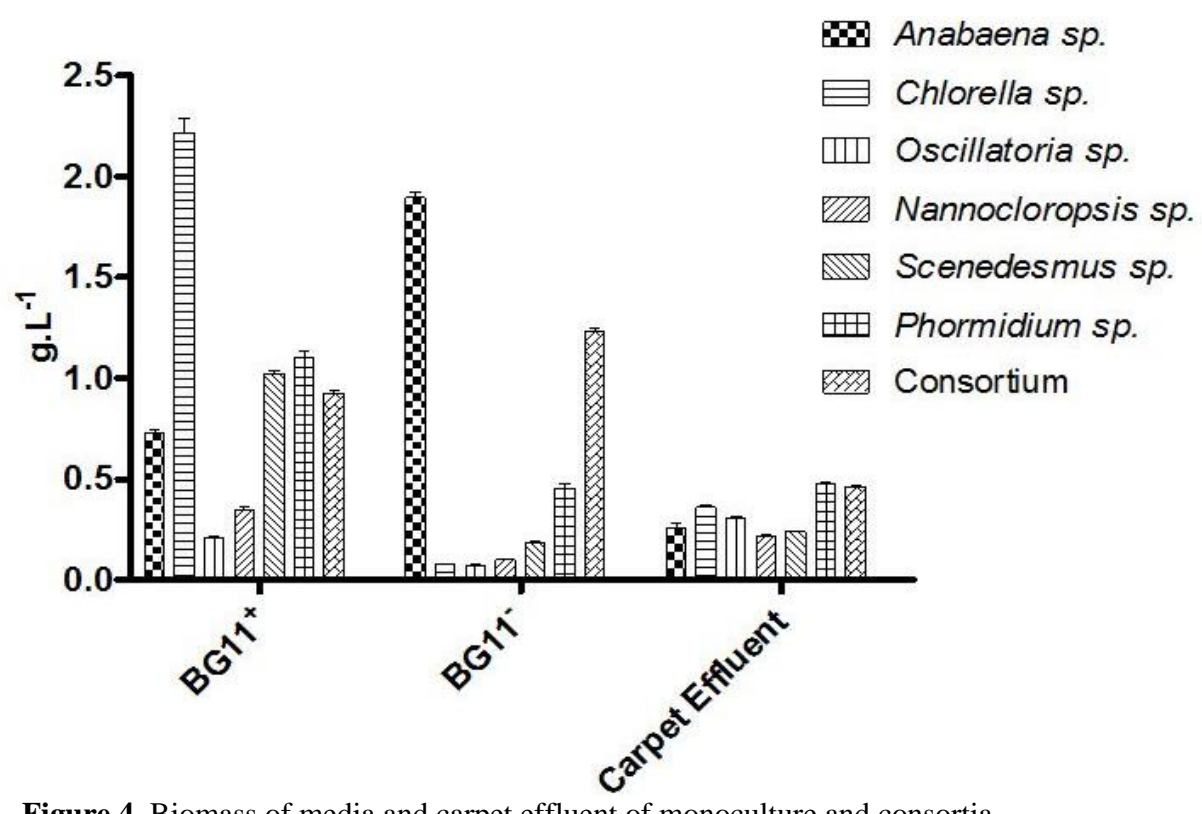

Figure 4. Biomass of media and carpet effluent of monoculture and consortia. 
A number of published articles are available dealing with how the different species of Chlorella sp. behaves in the nitrogen enriched environment, and utilised for the large-scale biomass production. In general, various species of Chlorella sp. needs nitrogen and nutrient enriched water for their healthy growth. Therefore, it grew

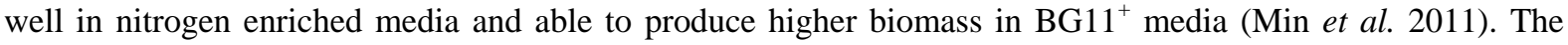
algae consortia produced second highest biomass in nitrate deficient BG11- media after Anabaena sp. It clarifies that under nitrogen depleted conditions and in the presence of phosphate Anabaena sp. can efficiently fix the nitrogen to produce biomass (Buikema \& Haselkor 1991). However, when Anabaena sp. was grown in consortia the nitrogen fixed by it got used up by other non-nitrogen fixing organisms for their healthy growth. Possibly, some of these organisms inhibited the growth of Anabaena sp. by producing the biochemicals that have allelopathic interactions (Hu \& Hong 2008). Anabaena sp., it may be responsible for inhibiting the growth of other organisms in the consortia. Therefore, biomass yield of consortia was found to be less than Anabaena sp. In the CE maximum biomass yield was recorded with Phormidium sp. $\left(0.48 \pm 0.010 \mathrm{~g} . \mathrm{L}^{-1}\right)$ followed by algae consortia $\left(0.460 \pm 0.010\right.$ g. $\left.\mathrm{L}^{-1}\right)$. As Phormidium sp. has a strong capability to grow in nutrient enriched or polluted water (De-Bashan \& Bashan 2010), and carpet effluent is a natural source of a list of hazardous heavy metals, therefore, due to its inherent traits to utilise all these things as supplements for healthy growth could ultimately help it to produce the highest biomass in CE water.

\section{Nitrate, Nitrite and Phosphate estimation}

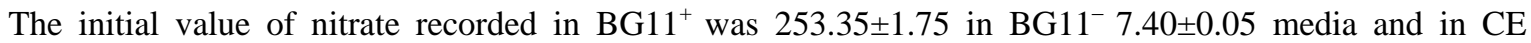
$1.08 \pm 0.10 \mathrm{mg} . \mathrm{L}^{-1}$. From the growth of synthetic consortia in $\mathrm{BG} 11^{+}$media nitrate content was enhanced by $295.27 \%$ (748.08 mg. $\mathrm{L}^{-1}$ ) while its cultivation in nitrate deficient BG11 ${ }^{-}$media resulted in a decrease of $68.91 \%$ (5.1 mg. $\left.\mathrm{L}^{-1}\right)$ due to biosorption of nitrate from media (Table 1). However, in CE media $123.14 \%\left(1.33 \mathrm{mg} . \mathrm{L}^{-1}\right)$ increase in the nitrate content was obtained. Overall in nitrogen rich BG11 ${ }^{+}$media, algae consortia synthesized the nitrate and efficiently participated in the bio-addition process. In BG $11^{+}$media Nannochloropsis sp., Phormidium sp. and consortia synthesized nitrate while other algae used the nitrate from the media and significantly contributed in biosorption process. Cultivation of nitrogen fixing microalgae Anabaena sp. in BG11 ${ }^{-}$media significantly enhanced the nitrate content by $1258.10 \%\left(93.1 \mathrm{mg} . \mathrm{L}^{-1}\right)$. In contrast, almost all the microalgae species and consortia depleted the nitrate to the surrounding habitat in the $\mathrm{CE}$ water that resulted in the valuable quantity of biomass production.

Table 1. Nitrate concentration of initial, monoculture and consortia.

\begin{tabular}{|c|c|c|c|}
\hline Algae & $\begin{array}{l}\text { BG11 }^{+} \\
\left(\text {Nitrate }_{\text {mg.L }}{ }^{-1}\right)\end{array}$ & $\begin{array}{l}\text { BG11 }^{-} \\
\text {(Nitrate mg.L }{ }^{-1} \text { ) }\end{array}$ & $\begin{array}{l}\text { Carpet effluent } \\
\left(\text { Nitrate } \text { mg.L }^{-1}\right)\end{array}$ \\
\hline Initial (Blank) & $253.35 \pm 1.75$ & $7.40 \pm 0.05$ & $1.08 \pm 0.10$ \\
\hline Anabaena sp. & $113.23 \pm 0.87$ & $100.50 \pm 1.25$ & $2.13 \pm 0.15$ \\
\hline Chlorella sp. & $85.45 \pm 0.56$ & $3.58 \pm 0.35$ & $3.18 \pm 0.07$ \\
\hline Oscillatoria sp. & $152.53 \pm 2.10$ & $1.3 \pm 0.05$ & $44.26 \pm 1.04$ \\
\hline Nannochloropsis sp. & $271.80 \pm 1.32$ & $1.94 \pm 0.04$ & $2.31 \pm 0.07$ \\
\hline Scenedesmus sp. & $191.96 \pm 6.04$ & $3.75 \pm 0.15$ & $2.48 \pm 0.07$ \\
\hline Phormidium sp. & $341.43 \pm 3.46$ & $1.90 \pm 0.05$ & $2.31 \pm 0.07$ \\
\hline Consortia & $1001.19 \pm 6.53$ & $2.30 \pm 0.15$ & $2.41 \pm 0.07$ \\
\hline
\end{tabular}

Table 2. Nitrites concentration of initial, monoculture and consortia.

\begin{tabular}{|c|c|c|c|}
\hline Algae & $\begin{array}{l}\text { BG11 }^{+} \\
\left(\text {Nitrate }_{\text {mg.L }}{ }^{-1}\right)\end{array}$ & $\begin{array}{l}\text { BG11 }^{-} \\
\left(\text {Nitrate }_{\text {mg.L }}{ }^{-1}\right)\end{array}$ & $\begin{array}{l}\text { Carpet effluent } \\
\left(\text { Nitrate } \text { mg.L }^{-1}\right)\end{array}$ \\
\hline Initial (Blank) & $0.0 \pm 0.000$ & $0.00 \pm 0.000$ & $0.011 \pm 0.002$ \\
\hline Anabaena sp. & $0.397 \pm 0.012$ & $0.154 \pm 0.005$ & $0.026 \pm 0.004$ \\
\hline Chlorella sp. & $1.427 \pm 0.008$ & $0.022 \pm 0.004$ & $0.022 \pm 0.003$ \\
\hline Oscillatoria sp. & $4.732 \pm 0.023$ & $0.025 \pm 0.005$ & $0.208 \pm 0.006$ \\
\hline Nannochloropsis sp. & $12.807 \pm 0.169$ & $0.025 \pm 0.004$ & $0.017 \pm 0.004$ \\
\hline Scenedesmus sp. & $18.420 \pm 0.270$ & $0.119 \pm 0.003$ & $0.039 \pm 0.004$ \\
\hline Phormidium sp. & $13.710 \pm 0.135$ & $0.036 \pm 0.005$ & $0.018 \pm 0.003$ \\
\hline Consortia & $35.520 \pm 0.665$ & $0.038 \pm 0.004$ & $0.039 \pm 0.004$ \\
\hline
\end{tabular}


In comparison to nitrate the concentration of nitrites was increased in all the experiment. With inoculation of algae consortia the maximum increase in the concentration of nitrite was recorded in the $\mathrm{BG} 11^{+}$media, followed by $\mathrm{BG}_{11^{-}}$and $\mathrm{CE}$ respectively (Table 2 ). Microalgae consortia and monocultures showed varying performance towards bio-addition activity in different cultivation media. Maximum activity was recorded by consortia in the case of BG11 $1^{+}\left(35.52 \mathrm{mg} . \mathrm{L}^{-1}\right.$ from zero value) followed by BG11 ${ }^{-}\left(0.038 \mathrm{mg} . \mathrm{L}^{-1}\right.$ from zero value) and CE $254 \%$ $\left(0.028 \mathrm{mg} . \mathrm{L}^{-1}\right)$. Therefore, cultivation of these photosynthetic organisms significantly added the nitrate and nitrite in the nitrate enriched $\mathrm{BG} 11^{+}$media.

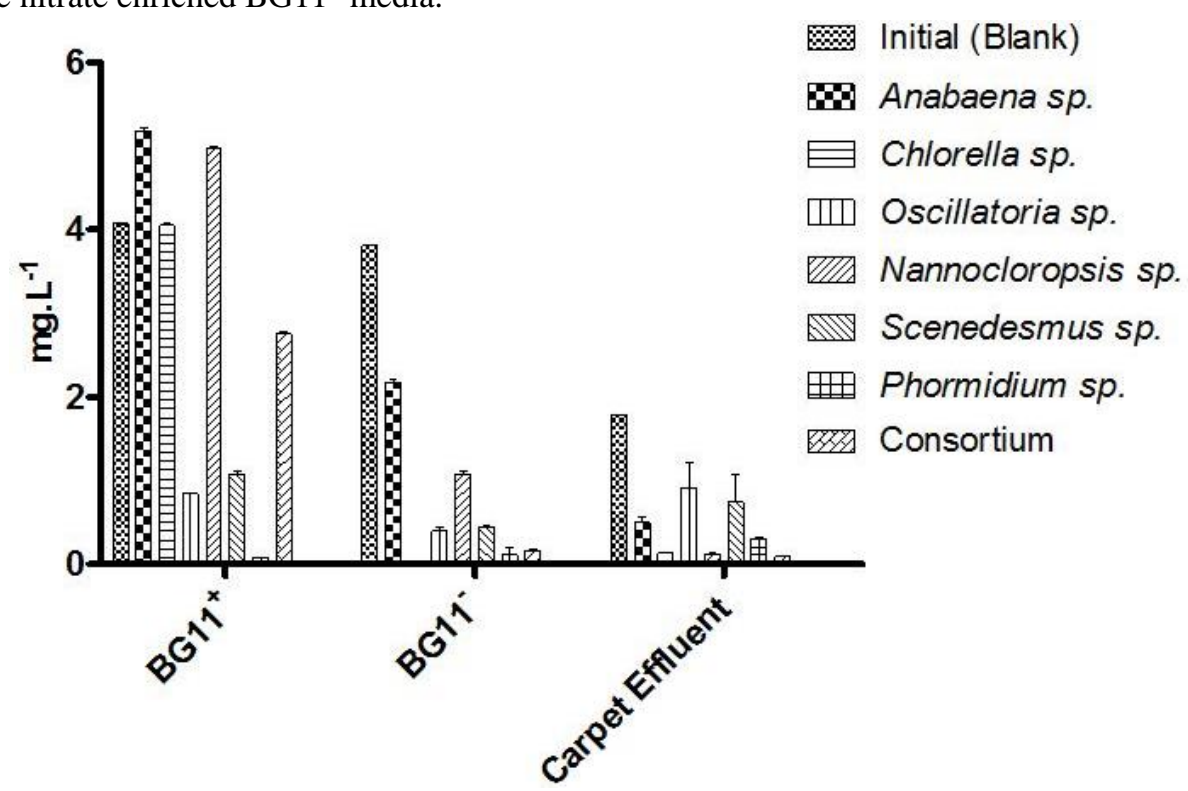

Figure 5. Phosphate of media and carpet effluent of blank (Initial) after growth of monoculture and consortia.

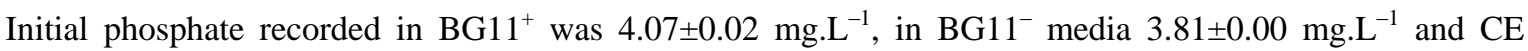

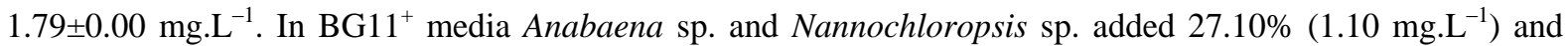
$22.28 \%\left(0.90 \mathrm{mg} . \mathrm{L}^{-1}\right)$ phosphate respectively whilst other algae and consortia were actively involved in its

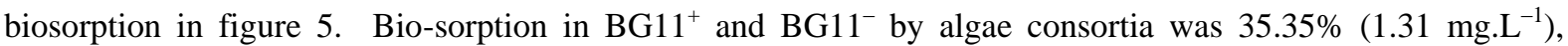
95.72\% (3.64 mg. $\left.\mathrm{L}^{-1}\right)$ and in CE water 94.97\% (1.7 mg. $\left.\mathrm{L}^{-1}\right)$ respectively. All monocultures and consortia significantly affected the phosphate absorptions $(P<0.001)$ except Chlorella sp. in $\mathrm{BG}_{1} 1^{+}(P>0.05$, ns $)$ media.

The ratio of nitrogen to phosphorus available for the growth of algae is an important parameter that determines the overall growth. The Redfield ratio of $106 \mathrm{C}: 16 \mathrm{~N}: 1 \mathrm{P}$ is commonly used to indicate the required ratio of carbon, nitrogen and phosphorus (Redfield 1958). Nitrogen is the second limiting factor in plant growth taken up by cells in the form of ammonia, nitrate and nitrite (Evans 2001). Phosphorus is the third most important macronutrient that is absorbed by plant cells in the form of phosphate. It can bind to other ions and precipitate and enhance its limiting concentrations for optimal growth (Xin et al. 2010). With enhanced nitrogen levels bio-sorption of phosphorus decreases (Grobbelaar 2004). Hence, uptake of phosphate depends on the availability of nitrate. In $\mathrm{BG}_{1} 1^{+}$media supplementation of sodium nitrate decreased the phosphate absorption.

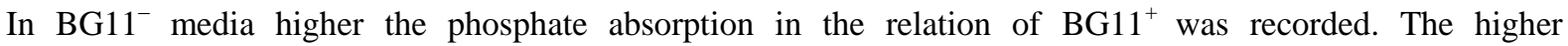
concentrations of nitrate in media provoke the fixation of nitrogen by heterocystous filamentous and unicellular morphological types of algae (Philips et al. 1992). However, higher nitrate content reduces the biosorption of nitrate. In the presence of higher concentrations of nitrate, some algae synthesize nitrate (Manhart \& Wong 1980, Philips et al. 1992). Nitrogen is mainly involved in the synthesis of proteins; therefore, low nitrogen supply limits the synthesis of required amounts of the proteins (Geider \& Roche 2002, Loladze \& Elser 2011) that alternatively results in a low number of ribosomes and the total amount of ribosomal RNA. Since most of the phosphate in the cell is stored in the ribosomal RNA, reduced numbers of the ribosomes are due to the lowering of cellular phosphate levels (Sterner \& Elser 2002, Beuckels et al. 2015).

In microalgae consortia high nitrate content could not influence the higher biomass synthesis. However, low nitrate supply enhanced the higher biomass synthesis due to the association of nitrogen fixating as well as nonnitrogen fixating algae species. In general, at the low nitrogen supply higher biomass yields are reported (Arumugam et al. 2013). On other hand, higher content of nitrate in media reduces the biosorption of phosphate by microalgae. However, in CE algae growth released very little nitrate in wastewater. Therefore, with limited www.tropicalplantresearch.com 
or lower supply of nitrates the rate of nitrate and phosphate bio-absorption was found to be higher (Ma et al. 2012, Zhang \& Hong 2014). High nitrate concentration induced the 'nitrate reductase' activity to form nitrite which alternatively converted to the ammonium ion by the action of another enzyme 'nitrite reductase'. Nitrate reductase is inhibited by nitrite and ammonium ions, regulators of the nir operon (Jha et al. 2007). In nonnitrogen fixing cyanobacteria, nitrate, nitrites and ammonium ions chiefly regulate the nir operon by fine-tuning the activity of nitrate reductase (NR) enzyme. Nitrate is utilized as the chief source of inorganic nitrogen for the majority of plants (Li et al. 2010) and is converted to ammonium (Stitt et al. 2002). Nitrate reduces to ammonia in two consequent steps, first, the reduction of nitrate to nitrite which is catalyzed by $\mathrm{NADH}_{2}$-nitrate reductase enzyme and secondly, the reduction of nitrite to ammonia that is catalyzed by ferredoxin-nitrite reductase. The presence of ammonia suppresses the uptake of nitrate by inactivating the nitrate reductase system by ammonia (Losada et al. 1970, Herrera et al. 1972, Serra et al. 1978). As a result, nitrate was synthesized with supplementation of high nitrate levels (Hansell et al. 2004). Some algae synthesize several types of phosphate enzymes such as alkaline phosphates, acid phosphates and protein phosphates. 'Phosphatase' is an enzyme that removes a single phosphate group from its substrate through hydrolysis of phosphoric monoesters into a phosphate (Babić et al. 2013). Therefore, uptake of phosphate is dependent upon the supply of nitrate and with low supply of nitrate biosorption of phosphate increases. Similarly, with high nitrate, biosorption of phosphate from waste water was decreased (Beuckels et al. 2015) with inoculation of these organisms.

\section{CONCLUSION}

Microalgae monocultures and synthetic consortia are capable biosorption of phosphate in the media and CE water, and played distinct roles in the ecosystem by altering the $\mathrm{DO}, \mathrm{pH}$ and conductivity. It was observed in the present experiment where a higher amount of phosphate was removed from $\mathrm{BG}_{11^{-}}$and $\mathrm{CE}$ water in comparison

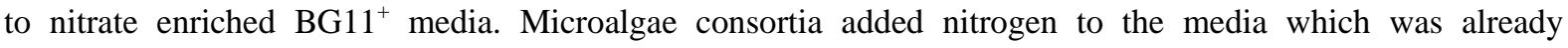
supplemented with considerable amounts of nitrogen i.e. BG11 ${ }^{+}$media. Therefore, presence of nitrogen enhances the bio-addition of nitrogen to media. To optimize the services of these monocultures in their natural habitats, there is a need to screen the suitable candidate algae species that might be helpful in mitigating the nutrient levels, and that can produce affordable amounts of biomass. Consequently, by applying the modern principles of the synthetic ecology suitable consortia of selected algae species can be developed that could be a sustainable way of a better method for waste water treatment and biomass production at industrial scale. Synthetic consortia of BG11 $1^{-}$could be helpful in getting the valuable amounts of biomass by adjusting the DO, $\mathrm{pH}$, conductivity and biosorption of nitrate and phosphate. Carpet effluent is a rich source of nutrients, therefore, it can be targeted as media for such algae species which could improve the water quality and simultaneously can produce the biomass for various algae based value added bio-processes.

\section{ACKNOWLEDGEMENTS}

This research was financially supported by UGC, New Delhi under UGC-SRF fellowship. We are thankful to Director, CSIR-NBRI, Lucknow for his constant support, encouragement and necessary laboratory facilities during the course of this research work. Dr. Kiran Toppo, Technical Officer and member of algae laboratory are thanked for her cooperation during the study.

\section{REFERENCES}

Abdelaziz AEM, Leite GB \& Hallenbeck PC (2013) Addressing the challenges for sustainable production of algal biofuels: I. Algal strains and nutrient supply. Environmental Technology 34: 1783-1805.

Akerström AM, Mortensen LM, Rusten B \& Gislerød HR (2014) Biomass production and nutrient removal by Chlorella sp. as affected by sludge liquor concentration. Journal of Environmental Management 144: 118124.

Anonymous (2012) United States Environmental Protection Agency. Water: Monitoring and Assessment. EPA. Available from: http://water.epa.gov/type/rsl/monitoring/vms59.cfm.2 (accessed: 20 July 2012).

Arbib Z, Ruiz J, Alvarez-Diaz P, Garrido-Perez C, Barragan J \& Perales JA (2013) Photobiotreatment: Influence of nitrogen and phosphorus ratio in wastewater on growth kinetics of Scenedesmus obliquus. International Journal of Phytoremediation 15: 774-788.

Arumugam M, Agarwal A, Arya MC \& Ahmed Z (2013) Influence of nitrogen sources on biomass productivity of microalgae Scenedesmus bijugatus. Bioresource Technology 131: 246-249. 
Aslan S \& Kapdan IK (2006) Batch kinetics of nitrogen and phosphorus removal from synthetic wastewater by algae. Ecological Engineering 28: 64-70.

Babić OB, Simeunović JB, Škrbić NZ, Kovač DJ \& Svirčev ZB (2013) Detection of phosphatase activity in aquatic and terrestrial cyanobacterial strains. Zbornik Matice Srpske Za Prirodne Nauke 125: 31-42.

Badran MI (2001) Dissolved oxygen, chlorophyll a and nutrients: seasonal cycles in waters of the Gulf Aqaba, Red Sea. Aquatic Ecosystem Health \& Management 4(2): 139-150.

Beuckels A, Smolders E \& Muylaert K (2015) Nitrogen availability influences phosphorus removal in microalgae-based wastewater treatment. Water Research 77: 98-106.

Buikema WJ \& Haselkor R (1991) Isolation and Complementation of Nitrogen Fixation Mutant of the Cyanobacterium Anabaena sp. Strain PCC 7120. Journal of Bacteriology 173(6): 1879-1885.

Cai T, Park SY \& Li Y (2013) Nutrient recovery from wastewater streams by microalgae: status and prospects. Renewable and Sustainable Energy Reviews 19: 360-369.

Chakraborty M, Miao C, McDonald A \& Chen SL (2012) Concomitant extraction of bio-oil and value added polysaccharides from Chlorella sorokiniana using a unique sequential hydrothermal extraction technology. Fuel 95(1): 63-70.

Christenson L \& Sims R (2011) Production and harvesting of microalgae for wastewater treatment, biofuels, and bioproducts. Biotechnology Advances 29: 686-702.

Craggs R, Lundquist T \& Benemann J (2013) Wastewater treatment and algal biofuel production. In: Borowitzka MA \& Moheimani NR (eds) Algae for Biofuels and Energy. Springer, Dordrecht, pp. 153-163.

De-Bashan LE \& Bashan Y (2010) Immobilized microalgae for removing pollutants: Review of practical aspects. Bioresource Technology 101: 1611-1627.

Dennis PP, Ehrenberg M, Fange D \& Bremer H (2009) Varying rate of RNA chain elongation during rrn transcription in Escherichia coli. Journal of Bacteriology 191: 3740-3746.

Desikachary TV (1959) Cyanophyta. Indian Council of Agricultural Research, New Delhi. pp.198, 250.

Elliot DC (2008) Catalytichydrothermal gasification of biomass biofuels. Bioproducts and Biorefining 2(3): 254-265.

Evans RD (2001) Physiological mechanisms influencing plant nitrogen isotope composition. Trends in Plant Science 6(3): 121-126.

French SL, Osheim YN, Cioci F, Nomura M \& Beyer AL (2003) In exponentially growing Saccharomyces cerevisiae cells, rRNA synthesis is determined by the summed RNA polymerase I loading rate rather than by the number of active genes. Molecular Cell Biology 23: 1558-1568.

Geider RJ \& La Roche JL (2002) Redfield revisited: variability of C: N: P in marine microalgae and its biochemical basis. European Journal of Phycology 37: 1-17.

Gilbert N, Fulthorpe R \& Kirkwood AE (2012) Microbial diversity, tolerance, and biodegradation potential of urban wetlands with different input regimes. Canadian Journal of Microbiology 58: 887-897.

Green FB, Lundquist TJ \& Oswald WJ (1995) Energetics of advanced integrated wastewater pond systems. Water Science and Technology 31: 9-20.

Grobbelaar JU (2004) Algal Nutrition-Mineral Nutrition. In Richmond A (ed) Handbook of Microalgal Culture. Blackwell Science Ltd., Oxford, UK, pp. 97-115.

Hansell DA, Bates NR \& Olson DB (2004) Excess nitrate and nitrogen fixation in the North Atlantic Ocean. Marine Chemistry 84: 243-265.

Henkanatte-Gedera SM, Selvaratnam T, Caskan N, Nirmalakhandan N, Van Voorhies W \& Lammers PJ (2015) Algal based, single step treatment of urban wastewaters. Bioresource Technology 189: 273-278.

Herrera J, Paneque A, Maldonado JM, Barea JL \& Losada M (1972) Regulation by ammonia of nitrate reductase synthesis and activity in Chlamydomonas reinhardi. Biochemical and Biophysical Research Communications 48: 996-1003.

Hibberd DJ (1981) Notes on the taxonomy and nomenclature of the algal classes Eustigmatophyceae and Tribophyceae (synonym Xanthophyceae). Botanical Journal of the Linnean Society 82: 93-119.

Hu H \& Hong Yu (2008) Algal-bloom control by allelopathy of aquatic macrophytes-A review. Frontiers of Environmental Science \& Engineering 2(4): 421-438.

Iyasele JU, David J \& Idiata DJ (2015) Investigation of relationship between Electrical conductivity and total dissolve solids for Mono-Valent, Di-Valent and Tri-Valent Metal Compound. International Journal of 
Engineering Research and Reviews 3(1): 40-48.

Jha P, Ali A \& Raghuram N (2007) Nitrate-Induction of Nitrate Reductase and its Inhibition by Nitrite and Ammonium Ions in Spirulina platensis. Physiology and Molecular Biology of Plants 13(2): 163-167.

Klausmeier CA, Litchman E, Daufresne T \& Levin SA (2004) Optimal nitrogen-to-phosphorus stoichiometry of phytoplankton. Nature 429: 171-174.

Li GJ, Peng FT, Zhang L, Shi XZ \& Wang ZY (2010) Cloning and characterization of a SnRK1 encoding gene from Malus hupehensis Rehd. and heterologous expression in tomato. Molecular Biology Reports 37: 947954.

Loladze I \& Elser JJ (2011) The origins of the Redfield nitrogen-to-phosphorus ratio are in a homoeostatic protein-to-rRNA ratio. Ecology Letters 14: 244-250.

Losada M, Paneque A, Aparicio PJ, Vega JM, Cárdenas J \& Herrera J (1970) Inactivation and repression by ammonium of the nitrate reducing system in Chlorella. Biochemical and Biophysical Research Communications 38: 1009-1015.

Lugtenberg B \& Kamilova F (2009) Plant-growth-promoting rhizobacteria. Annual Review of Microbiology 63: $541-556$.

Ma HF, Li X, Hu HY, Yu Y \& Wu YH (2012) Growth, removal of nitrogen and phosphorus, and lipid accumulation property of Scenedesmus sp. LX1 in aquaculture wastewater. Huan Jing ke Xue Huanjing Kexue 33: 1891-1896.

Manasrah R, Raheed M \& Badran MI (2006) Relationships between water temperature, nutrients and dissolved oxygen in the northern Gulf of Aqaba, Red Sea. Oceanologia 48(2): 237-253.

Manhart JR \& Wong PP (1980) Nitrate Effect on Nitrogen Fixation (Acetylene Reduction). Plant Physiology 65: 502-505.

McCarty PL, Bae J \& Kim J (2011) Domestic wastewater treatment as a net energy producer-can this be achieved? Environmental Science \& Technology 45(17): 7100-7106.

Min M, Wang L, Li Y, Mohr MJ, Hu B, Zhou W, Chen P \& Ruan R (2011) Cultivating Chlorella sp. in a PilotScale Photobioreactor Using Centrate Wastewater for Microalgae Biomass Production and Wastewater Nutrient Removal. Applied Biochemistry and Biotechnology 165: 123-137.

Oswald WJ, Gotaas HB, Golueke CG \& Kellen WR (1957) Algae in wastewater treatment. Sewage and Industrial Wastes 29: 437-457.

Philipose MT (1967) Chlorococcales. Indian Council of Agricultural Research, New Delhi, pp. 172, 245.

Philips EJ, Ihnat J \& Conroy M (1992) Nitrogen fixation by the benthic freshwater cyanobacterium Lyngbya wollei. Hydrobiologia 234: 59-64.

Piersma T \& Drent J (2003) Phenotypic flexibility and the evolution of organismal design. Trends in Ecology \& Evolution 18: 228-233.

Pittman JK, Dean AP \& Osundeko O (2011) The potential of sustainable algal biofuel production using wastewater resources. Bioresource Technology 102(1): 17-25.

Potapova M \& Charles DF (2003) Distribution of benthic diatoms in U.S. rivers in relation to conductivity and ionic composition. Freshwater Biology 48: 1311-1328.

Redfield AC (1958) The biological control of chemical factors in the environment. American Scientist 46: 205221.

Renuka N, Sood A, Ratha SK, Prasanna R \& Ahluwalia AS (2013) Evaluation of microalgal consortia for treatment of primary treated sewage effluent and biomass production. Journal of Applied Phycology 25(5): 1529-1537.

Samor` G, Samorı C, Guerrini F \& Pistocchi R (2013) Growth and nitrogen removal capacity of Desmodesmus communis and of a natural microalgae consortia in a batch culture system in view of urban wastewater treatment: part I. Water Research 47(2): 791-801.

Serra JL, Llama MJ \& Cadenas E (1978) Characterization of the nitrate reductase activity in the diatom Skeletonema costatum. Plant Science Letters 13: 41-48.

Smith VH \& Schindler DW (2009) Eutrophication science: where do we go from here? Trends in Ecology \& Evolution 24(4): 201-207.

Sterner R \& Elser J (2002) Ecological Stoichiometry: the Biology of Elements from Molecules to the Biosphere. Princeton University Press, Princeton, NJ. 
Stitt M, Muller C, Matt P, Gibon Y, Carillo P, Morcuende R, Scheible WR \& Krapp A (2002) Steps towards an integrated view of nitrogen metabolism. Journal of Experimental Botany 53: 959-970.

Subashchandrabose SR, Ramakrishnan B, Megharaj M, Venkateswarlu K \& Naidu R (2011) Consortia of cyanobacteria/microalgae and bacteria: Biotechnological potential. Biotechnology Advances 29: 896-907.

Townsend SA, Garcia EA \& Douglas MM (2012) The response of benthic algal biomass to nutrient addition over a range of current speeds in an oligotrophic river. Freshwater Science 31(4): 1233-1243.

Wurts WA \& Durborow RM (1992) Interactions of pH, Carbon Dioxide, Alkalinity and Hardness in Fish Ponds. Southern Regional Aquaculture Center. Publication No. 464.

Xin L, Hu HY, Ke G \& Sun YX (2010) Effects of different nitrogen and phosphorus concentrations on the growth, nutrient uptake, and lipid accumulation of a freshwater microalga Scenedesmus sp. Bioresource Technology 101: 5494-5500.

Yeh JT, Resnik KP, Rygle K \& Pennline HW (2005) Semi-batch absorption and regeneration studies for $\mathrm{CO}_{2}$ capture by aqueous ammonia. Fuel Processing Technology 86: 1533-1546.

Zhang Q \& Hong Y (2014) Effects of stationary phase elongation and initial nitrogen and phosphorus concentrations on the growth and lipid-producing potential of Chlorella sp. HQ. Journal of Applied Phycology 26: 141-149. 